\title{
KEHIDUPAN PENGHUNI LANJUT USIA DI RUMAH SUSUN
}

\author{
Sigit Wijaksono \\ Architecture Department, Faculty of Engineering, Binus University \\ Jln. K.H. Syahdan No. 9, Palmerah, Jakarta Barat 11480 \\ swijaksono@binus.edu
}

\begin{abstract}
Any provision of public facilities and infrastructure should provide accessibility for elderly to create a more supportive situation and environment for them in carrying out their social functions and active roles in community life as naturally, state and nation. Accessibility in this case is the availability of public facilities and infrastructure that can facilitate the mobility of elderly in public places, such as wheelchair ramp, the path for stick users, doors, stairs, elevators for multi-storey buildings, and pedestrian crossing. This accessibility can be both physical and non physical. In this research what to be studied is how the implementation of the existing flats can provide accessibility to the elderly residents. Using descriptive exploratory method the condition of their perceptions of occupied flats will be described. This study is carried out qualitatively using interviews.
\end{abstract}

Keywords: elderly, accessibility, public facilities and infrastructure, flats

\begin{abstract}
ABSTRAK
Setiap pengadaan sarana dan prasarana umum harus menyediakan aksesibilitas bagi para lanjut usia untuk menciptakan keadaan dan lingkungan yang lebih menunjang bagi mereka dalam melaksanakan fungsi sosialnya dan peran aktif secara wajar dalam hidup bermasyarakat, berbangsa dan bernegara. Aksesibilitas dalam hal ini adalah tersedianya sarana dan prasarana umum yang dapat memudahkan mobilitas para lanjut usia di tempat-tempat umum, seperti jalan untuk kursi roda, jalan untuk mereka yang bertongkat, pintu, tangga, lift khusus untuk bangunan bertingkat, dan tempat penyeberangan pejalan kaki. Penyediaan aksesibilitas ini dapat berbentuk fisik dan non fisik. Yang akan diteliti dalam penelitian ini adalah bagaimana penyelenggaraan rumah susun yang ada dapat memberikan kemudahan bagi para penghuni lanjut usia. Dengan menggunakan metode deskriptif eksploratif akan digambarkan kondisi mereka dan persepsinya terhadap rumah susun yang dihuni. Penelitian ini bersifat kualitatif menggunakan wawancara.
\end{abstract}

Kata kunci: lanjut usia, aksesibilitas, sarana dan prasarana, rumah susun 


\section{PENDAHULUAN}

Manusia lanjut usia adalah seseorang yang karena usianya mengalami perubahan biologis, fisik, kejiwaan, dan sosial, perubahan ini akan memberikan pengaruh pada seluruh aspek kehidupan, termasuk kesehatannya. Oleh karena itu, kesehatan manusia lanjut usia perlu mendapatkan perhatian khusus dengan tetap dipelihara dan ditingkatkan agar selama mungkin dapat secara produktif sesuai dengan kemampuannya sehingga dapat ikut serta berperan aktif dan pembangunan. Kelompok lanjut usia adalah keelompok penduduk yang berusia 60 tahun keatas (Hadywinoto dan Setiabudhi, 1999). Pada lanjut usia akan terjadi proses menghilangnya kemampuan jaringan untuk memperbaiki diri atau mengganti dan mempertahankan fungsi normalnya.

Bab III, Hak dan Kewajiban, Pasal 5 UU No. 13 Tahun 1998 tentang Kesejahteraan Lanjut Usia, menyebutkan bahwa lanjut usia mempunyai hak yang sama dalam kehidupan bermasyarakat, berbangsa, dan bernegara. Kemudian sebagai penghormatan dan penghargaan kepada lanjut usia diberikan hak untuk meningkatkan kesejahteraan sosial yang meliputi, antara lain kemudahan dalam penggunaan fasilitas, sarana, dan prasarana umum. Selanjutnya penjabaran sebagai pemberian penghormatan dan penghargaan kepada lanjut usia tersebut dirinci pada Peraturan Pemerintah No. 43 Tahun 2004 tentang Pelaksanaan Upaya Peningkatan Kesejahteraan Sosial Lanjut Usia.

Kajian Komisi Nasional Lanjut Usia pada Tahun 2009 mendapatkan bahwa jumlah instansi yang seharusnya memberikan layanan terhadap lanjut usia masih sangat terbatas. Tragis memang, kemajuan di bidang pembangunan yang dicapai pemerintah tidak diikuti dengan tingkat partisipasi instansi pemerintah maupun swasta dalam upaya peningkatan kesejahteraan lanjut usia. Pelayanan untuk mendapatkan kemudahan dalam penggunaan fasilitas, sarana dan sarana umum sudah menjadi tuntutan yang wajib dipenuhi oleh pemerintah dan masyarakat, namun masih terlihat dimana-mana belum adanya pelaksanaan yang menyeluruh. Berikut ini kemudahan dalam penggunaan fasilitas, sarana dan prasarana umum yang terdapat dalam peraturan perundang-undangan tersebut, yaitu: (1) pelayanan kesehatan untuk memelihara dan meningkatkan derajat kesehatan dan kemampuan lanjut usia agar kondisi fisik, mental dam sosialnya dapat berfungsi secara wajar; (2) pelayanan untuk mendapatkan kemudahan dalam penggunaan fasilitas, sarana, dan prasarana umum sebagai perwujudan rasa hormat dan penghargaan kepada lanjut usia, melalui pemberian kemudahan dalam pelayanan administrasi pemerintah dan masyarakat pada umumnya.

Lanjut Usia digolongan menjadi tiga kelompok menurut Departemen Kesehatan, yaitu: kelompok lanjut usia dini (55-64 tahun), merupakan kelompok yang baru memasuki lanjut usia; kelompok lanjut usia (65 tahun ke atas); dan kelompok lanjut usia resiko tinggi, yaitu yang berusia lebih dari 70 tahun. Berdasarkan ketentuan ini, tipe-tipe bangunan dengan penggunaan tertentu diwajibkan untuk memenuhi persyaratan teknis tersebut (Tabel 1).

Tabel 1

Jenis-Jenis Bangunan yang Wajib Menyediakan Aksesibilitas dan Kemudahan

\begin{tabular}{ll}
\hline \multicolumn{1}{c}{ Jenis Bangunan } & \multicolumn{1}{c}{ Ketentuan Minimum } \\
\hline $\begin{array}{l}\text { Kantor bank, kantor pos dan kantor jasa pelayanan } \\
\text { masyarakat yang sejenis }\end{array}$ & $\begin{array}{l}\text { Paling sedikit menyediakan satu buah meja } \\
\text { atau kantor pelayanan yang aksesibel }\end{array}$ \\
$\begin{array}{l}\text { Toko dan bangunan-bangunan perdagangan jasa sejenis } \\
\text { Hotel, penginapan dan bangunan sejenis }\end{array}$ & $\begin{array}{l}\text { Seluruh area perdangan harus aksesibel } \\
\text { Paling sedikit satu kamar tamu/ tidur dari }\end{array}$ \\
& setiap 200 kamar tamu yang ada dan \\
Bangunan pertunjukkan, bioskop, stadion dan bangunan & kelipatan darinya harus aksesibel \\
sejenis dimana susunan tempat duduk permanen & Paling sedikit dua area untuk kursi roda \\
tersedia. & untuk setiap 400 tempat duduk yang ada dan \\
& kelipatannya yang sebanding dengan yang \\
& harus tersedia
\end{tabular}


Bangunan keagamaan

Bangunan asrama dan sejenisnya

Restoran dan tempat makan di luar ruangan
Seluruh area untuk persembahyangan harus aksesibel

Paling sedikit satu kamar, yang sebaiknya terletak pada lantai dasar, harus aksesibel. Paling sedikti satu meja untuk setiap sepuluh meja makan yang ada dan kelipatannya, harus aksesibel

Berdasarkan PP No. 43 Tahun 2004 tentang Pelaksanaan Upaya Peningkatan Kesejahteraan Sosial Lanjut Usia, sarana dan prasarana umum yang dapat diakses dengan mudah oleh lanjut usia, antara lain: kemudahan dalam penggunaan fasilitas umum, sarana dan prasarana umum; aksesibilitas pada bangunan umum, pada pertamanan dan tempat rekreasi, dan pada angkutan umum.

Aksesibilitas adalah tersedianya sarana dan prasarana umum yang dapat memudahkan mobilitas lanjut usia di tempat-tempat umum, seperti jalan untuk kursi roda, jalan bagi mereka yang bertongkat, pintu, tangga, lift khusus untuk bangunan bertingkat, dan tempat penyeberangan pejalan kaki. Setiap pengadaan sarana dan prasarana umum baik oleh pemerintah maupun oleh masyarakat yang telah dilaksanakan harus menyediakan aksesibilitas bagi lanjut usia. Penyediaan aksesibilitas bagi lanjut usia pada sarana dan prasarana umum sebagaimana yang dimaksud di atas adalah untuk menciptakan keadaan dan lingkungan yang lebih menunjang lanjut usia dalam melaksanakan fungsi sosialnya dan berperan aktif secara wajar dalam hidup bermasyarakat, berbangsa dan bernegara.

Penyediaan aksesibilitas bagi usia lanjut pada sarana dan prasarana umum dapat berbentuk: fisik dan non fisik. Aksesibilitas pada bangunan umum adalah keselamatan, yaitu setiap bangunan yang bersifat umum dalam suatu lingkungan terbangun, harus memperhatikan keselamatan bagi semua orang; kemudahan, yaitu setiap orang dapat mencapai semua tempat atau bangunan yang bersifat umum dalam suatu lingkungan; kegunaan, yaitu setiap orang dapat menggunakan semua tempat atau bangunan yang bersifat umum dalam suatu lingkungan; dan kemandirian, yaitu setiap orang harus bisa mencapai, masuk dan menggunakan semua tempat atau bangunan yang bersifat umum dalam satu lingkungan dengan tanpa membutuhkan bantuan orang lain.

Pasal 27 UU No. 28 tahun 2002 tentang Bangunan Gedung menyebutkan:

(1) persyaratan kemudahan sebagaimana dimaksud meliputi kemudahan hubungan ke, dari dan di dalam bangunan gedung, serta kelengkapan sarana dan prasarana dalam pemanfaatan bangunan gedung; (2) kemudahan hubungan ke, dari, dan di dalam gedung sebagaimana dimaksud meliputi tersedianya fasilitas dan aksesibilitas yang mudah, aman, dan nyaman termasuk bagi penyandang cacat dan lanjut usia; 3) kelengkapan sarana dan prasarana sebagaimana dimaksud pada bangunan gedung untuk kepentingan umum meliputi penyediaan fasilitas yang cukup untuk ruang, ruang ganti, ruangan bayi, toilet, tempat parkir, tempat sampah, serta fasilitas komunikasi dan informasi. Aksesibilitas pada bangunan umum sebagaimana disebutkan dilaksanakan dengan menydiakan: (1) akses ke, dari dan di dalam bangunan gedung; (2) tangga dan lift khusus untuk bangunan bertingkat; (3) tempat parkir dan tempat naik turun penumpang; (4) tempat duduk khusus; (5) pegangan tangan pada tangga, dinding kamar mandi, dan toilet; (6) telepon umum; (7) tempat minum; (8) tanda-tanda peringatan darurat dan sinyal.

Dari berbagai sarana dan prasarana umum yang dapat diakses oleh lanjut usia di dalam penelitian ini yang akan diteliti adalah aksesibilitas dan kemudahan bagi para lanjut usia di rumah susun. Menurut UU No. 4 Tahun 1992 tentang Rumah Susun, yang dimaksud dengan rumah susun adalah bangunan gedung bertingkat yang dibangun dalam suatu lingkungan yang terbagi dalam bagian-bagian yang distrukturkan secara fungsional dalam arah horisontal ataupun vertikal dan merupakan satuan-satuan yang digunakan terpisah, terutama untuk tempat hunian, yang dilengkapi 
dengan bagian bersama, dengan atau tanpa tanah bersama. Penyelenggaraan rumah susun berasaskan pada: (1) kesejahteraan; (2) keadilan dan pemerataan; (3) kenusantaraan; (4) efisiensi dan kemanfaatan; (5) keterjangkauan dan kemudahan; (6) kemandirian dan kebersamaan; (7) kemitraan; (8) keserasian dan keseimbangan; (9) keterpaduan; (10) kelestarian dan berkelanjutan. Salah satu tujuan dari penyelenggaraan rumah susun adalah untuk menjamin terwujudnya rumah susun yang layak huni dan terjangkau dalam lingkungan yang sehat, aman, harmonis, dan berkelanjutan serta menciptakan permukiman yang terpadu guna membangun ketahanan ekonomi, sosial dan budaya.

\section{METODE}

Berdasarkan atas latar belakang dan tujuan penelitian, disain penelitian yang digunakan adalah eksploratori riset, yaitu penelitian yang diadakan untuk mendapatkan suatu gambaran dari fenomena tertentu. Berdasarkan jenis datanya, penelitian ini tergolong kualitatif. Teknik pengumpulan datanya menggunakan wawancara mendalam terhadap responden dan informan. Responden yang dipilih diharapkan dapat mewakili kelompok lanjut usia berdasarkan Depkes, yaitu kelompok lanjut usia dini, lanjut usia, dan lanjut usia rentan. Dalam penelitian ini lokasi penelitian yang dipilih adalah Rumah Susun Benhil II dan Rumah Susun Tebet. Dari masing-masing lokasi penelitian dapat diperoleh satu informan dan delapan responden.

\section{HASIL DAN PEMBAHASAN}

\section{Gambaran Umum Lokasi Penelitian}

Rumah susun Benhil II terletak di Jalan pernjernihan I, perjompongan, Jakarta Pusat. Unit rumah susun Benhill II bertipe studio, yaitu satu ruang besar polos, dapur, kamar mandi dan teras. Luas setiap unitnya sama yaitu $21 \mathrm{~m}^{2}$. Unit-unit di rumah susun ini sudah pada direnovasi sehingga bagian tembok sudah diplester dan lantai sudah diganti keramik serta diberi teralis. Seluruh rumah susun Benhil II terdiri atas tiga gedung. Masing-masing delapan lantai, menampung sekitar 250 unit hunian sehingga total ada 700 hunian. Sedangkan rumah susun Tebet yang sudah dikelola oleh PPRS, dibangun pada tahun 1995 dan status kepemilikannya dapat dijadikan hak milik (Rusunami), kecuali area yang diperuntukkan sebagai kawasan niaga. Rumah susun Tebet terdiri dari empat tower A, B, C, dan D setiap tower mempunyai lantai dasarnya yang diperuntukkan sebagai kawasan niaga. Untuk lantai dasar (unit niaga) berukuran $3 \mathrm{~m} \mathrm{X} 5 \mathrm{~m}$ dan untuk lantai 1 sampai lantai 3 masing-masing berukuran $24 \mathrm{~m}$. Kamar berukurnya $3 \mathrm{~m} \mathrm{X} 5 \mathrm{~m}$ dan sisanya untuk dapur, kamar mandi dan ruang jemur atau balkon. Setiap tower berjumlah 82 unit sehingga total keseluruhan tower adalah 328 unit. Fasilitas yang ada adalah: mushola, taman bermain anak, ruang gym, laundry, posyandu, pusat informasi dan konsultansi keluarga (PIK keluarga), parkir motor dan mobil dan telepon umum.

Berdasarkan hasil wawancara dengan salah satu informan, yaitu bapak Baskoro diperoleh gambaran bahwa di rumah susun Benhill II ini tersedia fasilitas lift akan tetapi tidak dapat digunakan untuk umum, melainkan hanya dipergunakan untuk perbaikan gedung saja. Fasilitas khusus untuk lanjut usia pun tidak ada atau belum tersedia dengan baik. Peraturan untuk lanjut usia pun belum ada karena yang tinggal dirumah susun ini tidak banyak yang lanjut usianya, kalaupun ada hanya sekitar 15 orang, sisanya adalah keluarga kecil, anak muda yang bekerja di sekitar Jakarta Pusat. Masih menurut bapak Baskoro, disain yang cocok untuk lanjut usia mungkin dengan adanya pembagian atau pengelompokkan untuk lanjut usia tinggal disekitar lantai 1-3 karena jika mereka tinggal di lantai atas, akan sulit bagi mereka untuk turun naik tangga karena di rumah susun Benhil II ini tidak tersedia lift untuk umum. 


\section{Hasil Pengumpulan Data Responden Rumah Susun Benhil II}

Berikut ini hasil wawancara dengan para responden di rumah susun Benhil II, diperoleh data sebagai berikut: Suyono, berusia 63 tahun yang berasal dari Palembang, Sumatera Selatan. Ia tinggal di rumah susun bersama dengan anaknya yang berusia 28 tahun dan dengan cucunya yang berusia tujuh tahun. Mereka tinggal sudah lebih dari tiga tahun dengan cara menyewa dan tinggal di lantai 6 . Suyono terkadang merasa kurang nyaman tinggal di rumah susun ini karena menurut beliau ukurannya yang sempit sehingga kurang mendapatkan ruang yang luas untuk beristirahat dengan tenang, ditambah dengan adanya cucu mereka yang aktif di usia tiga tahunan. Bapak Suyono membantu anaknya dengan berdagang peralatan rumah tangga, seperti ember, gayung, dan lain-lainnya. Setiap hari ia berjalan naik turun tangga dari lantai bawah menuju lantai 6 dengan susah payah karena mengingat usia beliau ini yang sudah cukup tua sehingga memerlukan waktu tempuh yang cukup lama untuk dapat naik dan turun menuju unit kamarnya. Fasilitas yang ada untuk lanjut usia tidak ada karena pada awalnya rumah susun ini diperuntukkan bagi anak muda, keluarga kecil yang masih cukup umur dan bukan untuk mereka yang lanjut usia. Interaksi yang terjalin antar anggota keluarga maupun tetangga di rumah susun ini menurut responden cukup baik, tetapi masih ada beberapa keluarga yang tertutup dan kurang mau bersosialisasi.

Eddy, berusia 59 tahun yang berasal dari Bekasi, Jawa Barat. Bapak ini tinggal bersama dengan istrinya yang berusia 47 tahun dan anak-anaknya yang masih kecil dan belum dapat mencari nafkah sendiri. Mereka tinggal di menyewa unit kamar rumah susun ini lebih dari satu setengah tahun di lantai 3. Ia merasa cukup nyaman tinggal di rumah susun ini walaupun ukuran unit kamar sempit. Bapak Eddy bekerja sebagai tukang bangunan dan dibantu anaknya dengan berjualan koran di pinggirpinggir jalan. Menurutnya, ia tidak terlalu sulit untuk menuju unit kamarnya karena tidak terlalu jauh dan responden masih merasa fisiknya masih kuat sehingga tidak masalah walaupun tinggal di unit kamar lantai atas pun. Ia menambahkan bahwa fasilitas yang ada untuk lanjut usia tidak ada karena rumah susun ini pada awalnya memang diperuntukkan bagi mereka yang masih berusia muda, keluarga kecil dan bukan untuk lanjut usia. Interaksi yang terjalin antar anggota keluarga maupun tetangga di rumah susun ini menurut responden karena responden dikenal sebagai orang yang ramah.

Darman, berusia 61 tahun yang berasal dari daerah Cirebon, Jawa Barat. Ia tinggal dengan istrinya saja yang berusia 54 tahun, dan baru menyewa unit kamar di rumah susun ini sekitar enam bulan di lantai 7. Bapak Darman merasa nyaman-nyaman saja tinggal di rumah susun ini. Menurutnya, tinggal di lantai paling atas dengan usia yang cukup tua memang membuat lelah. Akan tetapi menurut responden hal ini dianggap sebagai olahraga karena pekerjaannya pun sebagai tukang bersih-bersih rumah susun ini sehingga sudah menjadi hal yang biasa baginya. Pendapatnya tentang fasilitas yang ada untuk lanjut usia dengan responden yang lain. Interaksi di rumah susun ini menurut responden baik sekali karena bapak Darman bekerja sebagai tukang bersih-bersih sehingga sering bertemu dengan anggota masyarakat rumah susun di sekitarnya.

Jubaidah, berusia 65 tahun yang berasal dari Tangerang, Jawa Barat. Ia tinggal bersama dengan tiga anaknya, yang masing-msing berusia 23 tahun, 16 tahun dan 10 tahun. Mereka telah menyewa unit kamar rumah susun ini lebih dari 10 tahun dengan ukuran unit sama dengan unit lainnya yaitu bertipe studio yang berukuran $21 \mathrm{~m}^{2}$. Menurut responden merasa nyaman-nyaman saja tinggal di rumah susun ini karena sudah cukup lama tinggal. Responden tidak bekerja lagi karena merasa sudah berusia tua dan anaknya sudah dewasa sehingga pendapatan diperoleh dari anak-anaknya walaupun tidak terlalu banyak namun tetap dapat mencukupi kebutuhan hidup sehari-hari. Responden yang tinggal di lantai 1 merasa aksesnya tidak jauh dan tidak melelahkan. Fasilitas untuk lanjut usia di rumah susun ini tidak ada dan interaksi yang terjalin antar anggota keluarga maupun tetangga rumah susun ini baik sekali karena ibu Jubaidah tinggal sudah cukup lama. 
Wiwiek, berusia 53 tahun yang berasal dari Jakarta Utara. Ia tinggal bersama dengan suaminya yang berusia 63 tahun dan anaknya yang berusia 19 tahun selama lebih dari satu tahun dengan menyewa unit kamar di di lantai 5. Ibu Wiwiek merasa nyaman walaupun harus naik turun setiap hari sebanyak 5 lantai. Ibu Wiwiek bekerja dengan membuka usaha warung kecil yang berasa di sekitar rumah susun ini. Menurut responden faslitas yang ada untuk lanjut usia tidak ada dan interaksi yang terjalin antar anggota keluarga maupun tetangga rumah susun ini baik sekali.

Paino, berusia 63 tahun, berasal dari daerah Purwokerto, Jawa Tengah. Ia tinggal sendiri, dan sudah menempati rumah susun ini sekitar 8 tahun dengan menyewa unit kamar di lantai 5. Bapak paino merasa cukup nyaman karena berada cukup dekat dengan tempat bekerjanya. Bapak Paino bekerja sebagai tukang kayu di bengkel kusen sekitar rumah susun. Menurut bapak Paino tinggal di lantai 5 melelahkan karena kakinya suka berasa sakit dan pegal-pegal. Sekarang ia sudah merasa tidak kuat lagi karena faktor usia. Di rumah susun ini menurut responden tidak ada fasilitas untuk lanjut usia dan interaksi dengan tetangga cukup baik.

Ningsih, berusia 58 tahun, berasal dari daerah Solo, Jawa Tengah. Ia tinggal di lantai 5 bersama dengan dua anaknya yang berusia 8 dan 14 tahun serta suaminya yang bekerja sebagai tukang ojek dan berusia 62 tahun. Mereka sudah menempati rumah susun ini sekitar tujuh tahun dengan menyewa unit kamar rumah susun ini. Mereka merasa ukuran unitnya terlalu kecil dengan perabot rumah tangga yang cukup banyak. Ibu Ningsih bekerja sebagai tukang sayur keliling di sekitar rumah susun. Menurut responden tinggal di lantai 5, cukup jauh kadang terlalu cepat lelah karena sering naik turun dengan mengangkut barang-barang untuk jualan. Fasilitas untuk lanjut usia menurut responden tidak ada dan interaksi dengan tetangga rumah susun ini kenal dekat dengan masyarakat sekitar karena kesehariannya responden menjual sayur kepada mereka.

Sulastri, berusia 49 tahun yang berasal dari daerah Subang, Jawa Barat. Ia tinggal bersama suaminya yang berusia 57 tahun dan anaknya yang berusia 24 tahun dan sudah bekerja. Keluarga ibu Sulatri sudah menempati rumah susun ini sekitar empat tahun dengan menyewa unit kamar di rumah susun ini di lantai 4. Ibu Sulastri baru saja pindah dari Subang ke Jakarta untuk mencari nafkah yang lebih baik. Ibu Sulastri tinggal dan beliau merasa nyaman-nyaman saja, karena ibu Sulastri tidak bekerja karena suami dan anaknya sudah dapat mencari nafkah untuk kebutuhan sehari-hari, suaminya bekerja sebagai supir pribadi dan anaknya bekerja sebagai kurir. Menurut ibu Sulastri tinggal di lantai 4, akses untuk menuju unit kamar tidak terlalu berpengaruh karena ibu Sulastri jarang keluar rumah. Menurut responden fasilitas untuk lanjut usia tidak ada dan interaksi yang terjalin antar anggota keluarga maupun tetangga rumah susun kenal dekat dengan masyarakat kurang karena ibu Sulastri kurang bersosialisasi dengan orang-orang di lantai yang lain, hanya di sekitar orang-orang yang di lantai 4 saja.

\section{Hasil Pengumpulan Data Responden Rumah Susun Tebet}

Yati, berusia 63 tahun yang berasal dari daerah Jakarta. Ibu Yati tinggal bersama dengan anak perempuannya yang berusia 28 tahun dan telah mempunyai 1 orang anak laki-laki yang berusia 12 tahun. Keluarga ibu Yati telah menempati rumah susun ini selama 5 tahun. Ibu Yati tinggal di lantai dasar kawasan niaga yang berukuran $3 \mathrm{~m} \mathrm{X} 5 \mathrm{~m}$ di tower $\mathrm{C}$. Karena ukuran unitnya hanya yang sangat kecil, WC dan kamar mandinya berada di luar unit dan harus berbagi dengan sesama tetangga di lantai tersebut. Ibu Yati bekerja dengan membuka toko kelontong. Menurutnya, kawasan tempat tinggalnya sekarang ini sudah nyaman karena lingkungan sekitarnya ramah dan peduli terhadap sesama tetangga. Ibu Yati jarang keluar rumah, hanya berada di sekitar unitnya saja karena aktifitasnya berdagang. Fasilitas yang ada di rumah susun ini banyak, tapi tidak ada yang diperuntukkan khusus untuk lanjut usia. 
Soleh, berusia 72 tahun yang berasal dari daerah Depok, Jawa Barat. Bapak Soleh tinggal bersama dengan istrinya yang berusia 54 tahun. Keluarga bapak Soleh menempati rumah susun ini sudah selama dua tahun. Bapak Soleh tinggal di lantai dasar kawasan niaga yang berukuran $3 \mathrm{~m} \mathrm{X} 5 \mathrm{~m}$ saja di tower A. Bapak Soleh dan istrinya bekerja dengan membuka toko kelontong, sama seperti responden sebelumnya yaitu ibu Yati, tetapi berbeda tower. Menurut bapak Soleh selama tinggal di rumah susun ini beliau merasa aman dan nyaman. Bapak Soleh keluar rumah susun hanya kalau sedang mengambil barang untuk tokonya, sedangkan istrinya terus berada di dalam unit rumah susun dan jarang keluar. Menurut bapak Soleh fasilitas yang ada di rumah susun ini banyak namun memang tidak ada yang diperuntukkan khusus untuk lanjut usia. Masih mneurut bapak Soleh, kekurangan dari rumah susun ini hanya bila berada atau tinggal di lantai dasar, WC, dan kamar mandinya harus bersamaan dengan yang lainnya dan tidak dapat digunakan sendiri.

Alimin, berusia 68 tahun yang berasal dari daerah Kuningan, Jawa Barat. Selama 8 bulan ia tinggal sendiri di unit yang berukuran $3 \mathrm{~m} \mathrm{X} 5$ m di lantai dasar kawasan niaga tower D. Bapak Alimin bekerja dengan membuka toko kelontong. Menurut bapak Alimin, selama tinggal di rumah susun ini ia merasa nyaman sehingga ingin mengajak serta istrinya yang ada di kampung untuk tinggal bersama dengan bapak sekarang. Bapak Alimin keluar rumah susun hanya untuk mengambil barang dagangan untuk tokonya, karena tidak ada yang dapat menjaga toko bila ia sering keluar.

Jimmy, berusia 59 tahun yang berasal dari Cimanggis, Depok, Jawa Barat. Bapak Jimmy tinggal sendiri di unit rumah susun ini selama 9 tahun. Ia tinggal di tower A lantai 3 yang berukuran $24 \mathrm{~m}^{2}$. Ia masih bekerja sebagai karyawan swasta di suatu perusahaan. Menurutnya, selama tinggal di rumah susun ini ia merasa nyaman. Namun, ia termasuk orang yang cukup pendiam sehingga jarang melakukan interaksi dengan tetangga. Apalagi ia adalah seorang karyawan sehingga pergi pagi dan pulang sore bahkan hingga agak malam baru sampai di rumah susun ini. Bapak Jimmy sering keluar dan naik turun karena kamarnya berada di lantai 3. Hal itu tidak masalah baginya karena dianggap sebagai olahraga. Fasilitas yang ada di rumah susun ini banyak, tapi ia jarang menggunakannya selain mushola.

Hengky, berusia 64 tahun yang berasal dari daerah Jakarta. Ia tinggal bersama dengan istrinya yang berusia 57 tahun dan seorang cucu yang masih berumur 2 bulan dan sering dititipkan oleh anak mereka. Bapak Henky telah menempati rumah susun ini selama 12 tahun di tower $\mathrm{C}$ lantai 3 dengan unit berukuran $24 \mathrm{~m}^{2}$. Bapak Henky tidak bekerja. Menurutnya selama tinggal di rumah susun ini ia merasa sangat nyaman bahkan di lantai tempat tinggalnya diberikan tanaman hijau agar menjadi asri. Karena sudah tinggal lama di rumah susun ini, Bapak Henky banyak mengenal baik tetangganya, kecuali orang baru. Selain memberikan tanaman hijau, Bapak Henky juga melarang para tetangganya untuk menjemur baju di koridor karena akan mengganggu pemandangan. Menurutnya dengan usia yang sudah lebih dari setengah abad ini, naik turun tangga tidak terlalu sering ia dan istrinya lakukan. Mereka jarang sekali keluar dan hanya sering berada di lantai tempat mereka tinggal saja. Fasilitas yang ada di rumah susun ini cukup banyak, dan ada beberapa fasilitas yang sudah jarang digunakan, contohnya ruang gym yang seharusnya dapat juga digunakan sebagai ruang serbaguna.

Rina, berusia 51 tahun yang berasal dari Tangerang, Jawa Barat. Ia tinggal bersama dengan suaminya yang berusia 60 tahun. Ibu Rina telah menempati rumah susun selama 6 tahun di lantai 2 tower $\mathrm{D}$ dalam unit yang berukuran $24 \mathrm{~m}^{2}$. Ibu Rina berkerja sebagai pelayan restoran dan suaminya bekerja di bengkel. Menurutnya selama tinggal di rumah susun ini, ia merasa betah karena lingkungan rumah susun aman dan asri. Sering turun naik tangga untuk bekerja tidaklah mengganggu karena mereka merasa usia mereka belum terlalu tua dan masih merasa sehat. Fasilitas yang ada di rumah susun ini cukup banyak, dan ibu Rina sering berkumpul jika hari libur dengan ibu-ibu di sekitarnya.

Maria, berusia 53 tahun yang berasal dari Malang, Jawa Timur. Ia tinggal bersama dengan dua anaknya yang berumur 18 tahun dan 10 tahun selama 4 bulan. Mereka tinggal di lantai 4 yang berukuran $24 \mathrm{~m}^{2}$ di tower B. Ibu Maria bekerja sebagai kasir di sebuah swalayan. Ibu Maria merasa 
nyaman tinggal di rumah susun ini. Akan tetapi ia ingin pindah ke lantai yang lebih rendah karena ia sedikit takut pada ketinggian. Selain itu, bila membawa barang-barang yang cukup berat ke lantai 4, ia merasa cukup lelah. Fasilitas yang ada di rumah susun ini cukup banyak, walaupun ia tidak pernah menggunakan semuanya.

Dalam kegiatan sehari-hari, para lanjut usia yang berada di rumah susun Tebet ini melakukan aktivitas masing-masing. Ada yang tinggal dengan berjualan di unit kamarnya sendiri. Mereka sering berinteraksi dengan warga sekitarnya dengan bersosialisasi di depan unit kamar mereka yang biasa digunakan sebagai tempat berkumpul dengan orang-orang yang membeli barang kebutuhan di tempat mereka taupun warga lanjut usia lainnya yang bersosialiasi. Selain itu untuk lanjut usia yang tinggal di lantai 3 dengan bekerja sebagai karyawan swasta sering beraktivitas pada pagi harinya turun ke lantai dasar untuk keluar dari rumah susun menuju kantor tempatnya bekerja. Kemudian pulang lalu naik menuju unit kamarnya. Hal itu ia lakukan setiap harinya dari hari Senin hingga Sabtu. Lalu pada hari Minggunya ia lebih memilih berisitrahat di dalam unit rumah susunnya sendiri dan jarang berinteraksi dengan warga sekitarnya. Jika akan bersosialiasasi biasanya ia turun ke lantai dasar di dekat tangga untuk bercengkerama atau di depan warung atau took kelontong yang ada. Ada pula lanjut usia di lantai 3 yang tidak bekerja sehingga ia lebih sering berada di lantai tempat tinggalnya saja dan bersosialisasi pun dengan orang-orang di sekitar. Lalu untuk lanjut usia yang tinggal di lantai 2 bekerja di restoran dan bekerja di bengkel. Setiap hari mereka sering naik turun tangga dan mereka berosialisasi dengan warga sekitar hanya pada pagi dan sore hari saja pada saat sebelum kerja dan sesudah pulang kerja. Mereka bekerja jarang ada waktu libur yang pasti karena menjadi penjaga took di sebuha restoran tidak ada libur dan sangat jarang. Jika ada waktu libur, mereka beristirahat di unit rumah susunnya dan sering bersosialisasi pula di koridor depat unit rumah susun mereka, di lantai dasar dekat tangga dengan warga sekitarnya.

Lanjut usia yang tinggal di lantai 4 bekerja sebagai kasir di swalayan, ia sering turun naik tangga untuk menuju lantai dasar. Walaupun terasa melelahkan demi bekerja untuk mencari nafkah, hal itu dilakukan dengan hati yang senang. Jika ada waktu senggang atau libur, ia sering beristirahat di unit rumah susunnya saja. Jarang ia turun ke lantai dasar karena ia merasa lelah. Fasilitas yang ada di rumah susun Tebet ini yang digunakan oleh lanjut usia adalah mushola bagi para lanjut usia pria, taman bermain anak untuk anak atau cucu mereka yang balita serta untuk bersosialisasi dengan warga sekitarnya. Selain itu mereka dapat pula menggunakan posyandu, walaupun bukan khusus untuk lanjut usia akan tetapi mereka dapat menggunakannya jika mereka perlu melakukan pemeriksanaan kesehatan rutin. Ada pula fasilitas pusat informasi dan konsultasi keluarga (PIK keluarga) yang terkadang mereka datangi untuk mengkonssultasikan apa masalah yang mereka hadapi walaupun itu jarang terjadi dan digunakan.

\section{Perbandingan dengan Rumah Susun Khusus Lanjut Usia di Jepang}

Sebagai perbandingan dikaji satu rumah susun khusus untuk lanjut usia yang terletak di daerah Machida, yang berada sekitar satu jam perjalanan dari Tokyo dan sekitar 30 menit dari stasiun Machida ke area ini. Daerah ini juga dikenal dengan rumah susun yang sangat banyak dan juga para lanjut usia. Bentuk dan disain yang sederhana dan murah, ukuran yang tidak telalu besar sekitar 30-40 $\mathrm{m}$ dan ditempati oleh orang menengah ke bawah. Rumah susun ini sangatlah rapih dan bersih. Di satu area yang sangat luas, terbagi menjadi beberapa blok dan blok-blok digolongkan berdasarkan penghasilan si penghuni, misalnya yang berpenghasilan 1 juta per bulan di blok A dan diatas 1 juta per bulan di blok B. pembagian ini otomatis akan membedakan ukuran ruangan yang mereka tempati. Bagi orang jompo, mereka akan ditempatkan di lantai paling bawah (maksimal lantai 2) mengingat rumah susun ini tidak punya lift sehingga para orang jompo akan lebih mudah untuk masuk ke unit rumah mereka. Parkir mobil sangat terbatas tetapi bukan karena masalah lahan melainkan namanya untuk orang menengah ke bawah maka mobil tentu bukan merupakan benda yang banyak diminati 
oleh mereka, lagipula sistem transportasi sudah sangat nyaman. Tetapi di satu sisi disediakan tempat parkir mobil umum dimana masyarakat yang harus menyewa dan membayarnya setiap bulan.

Di sana terdapat jadwal untuk membuang sampah tertentu misalnya membuang sampah plastik setiap hari senin dan lainnya. Selain itu setiap bangunan disediakan tempat parkir mobil dengan jumlah hanya dapat memuat 10 mobil dan juga parkir motor atau sepeda.

Setiap jalan dibagi menjadi dua bagian, yaitu untuk pejalan kaki dan bersepeda dan juga untuk mobil. Walaupun bentuk bangunan sederhana, di setiap ruangan disediakan beberapa hal untuk para orang tua agar merasa aman walaupun tinggal sendirian, seperti tombol darurat baik di ruang tamu dan kamar mandi. Tombol darurat ini terhubung ke sebuah gedung dimana petugas menangani hal-hal yang darurat.

Adanya area hijau di setiap gedung memungkinkan setiap penghuni menanam apapun untuk membuat area mereka menjadi lebih indah. Walaupun area ini agak jauh dari stasiun, pemerintah di sana telah menyediakan sarana transportasi bus yang cukup nyaman dan setiap beberapa menit akan datang bus yang akan membawa penumpang ke stasiun disana. Di sini juga sama seperti di area lainnya di Jepang, bagi lanjut usia berumur 65 tahun ke atas gratis naik bus. Sarana transportasi inilah yang sangat penting mengingat rumah susun biasanya berada di daerah agak jauh dari pusat kota. Dengan sarana yang baik para lanjut usia mau tinggal di rumah susun.

\section{PENUTUP}

Masyarakat yang tinggal di rumah susun rata-rata berpenghasilan rendah dengan memilih lokasi dekat dengan lapangan pekerjaan mereka. Walaupun fasilitas serta disain yang diberikan oleh rumah susun tidak untuk penghuni khusus yang berusia lanjut, para lanjut usia yang tinggal di sana merasa nyaman dan puas dengan fasilitas yang ada. Karena mereka tidak mempunyai penghasilan yang cukup untuk rumah tinggal, mereka masih ingin tinggal di rumah susun sepanjang hidup mereka bisa mendapatkan penghasilan yang lebih baik dari anak cucu mereka masing- masing dan tidak menganjurkan anak cucu mereka untuk tinggal di rumah susun.

Dari hasil pengamatan dan survei, banyak sekali kekurangan dari rumah susun yang ada di Jakarta. Maka dari itu sangat dibutuhkan sebuah rancangan bangunan khusus untuk lanjut usia serta dengan adanya penambahan fasilitas khusus bagi lanjut usia untuk dapat memberikan kenyamanan bagi mereka yang tinggal di rumah susun.

\section{DAFTAR PUSTAKA}

Komisi Nasional Lanjut Usia. (2010), Aksesibilitas dan Kemudahan dalam Penggunaan Sarana dan Prasarana. Jakarta: Komisi Nasional Lanjut Usia.

Republik Indonesia. (1998). Undang-undang No. 13 tahun 1998 tentang Kesejahteraan Lanjut Usia. Jakarta: Biro Hukum BPKP. 